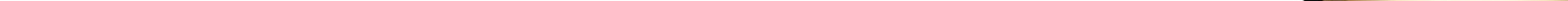




\section{Editorial: Thank You to CINEJ reviewers 2013}

\section{Murat Akser}

This issue of CINEJ is rich in content and diverse in its scholarship. We have received articles on cinema from every continent. This international, interdisciplinary and independent approach of CINEJ is appreciated by its readers. The open access nature of CINEJ is also embracesd by thousands of online researchers every day. We have added a festival review (TIFF 2013) and a book reviews section with this issue. In time we will have more sections and will appear more frequently in a year.

We could not have achieved such a high level of achievement without the support of our anonymous reviewers. The list below includes the names of scholars who anonymously reviewed submissions to CINEJ during 2013. The assesment of manuscripts prepared by these reviewers has contributed to the quality of scholarship CINEJ published during the year and we are very appreciative of this service.

$\begin{array}{lll}\text { Murat Akser } & \text { Gerd Gemunden } & \text { Colin MacCabe } \\ \text { Blain Allen } & \text { Selen Gökçem } & \text { Anna Maria McMurray } \\ \text { Eylem Atakav } & \text { Barry Keith Grant } & \text { CSHN Murthy } \\ \text { Deniz Bayrakdar } & \text { Paul Hartley } & \text { Donna Ong } \\ \text { Petra de Bruijn } & \text { John Hill } & \text { Erman Pehlivan } \\ \text { Fernando Canet } & \text { Dilek Kaya } & \text { Phoebe Pua } \\ \text { John Downing } & \text { Aslı Kotaman } & \text { Defne Tüzün } \\ \text { Alexander Fisher } & \text { Marcia Landy } & \text { Tom Vercruysse }\end{array}$

In this issue we have nine articles, one festival review and one book review. Nolwenn Anne Mingant in her article titled "Not A Terrorist': The Representational Alternative of Reality TV in All-American Muslim" debates that the reality TV show All-American Muslim depicting the lives of five Muslim families of Lebanese descent in Dearborn presents the reality TV format seems particularly apt at providing a different vision of American Muslim, a vision clashing with images usually conveyed by TV news and Hollywood films.

James Blake Ewing in his article argues that Abbas Kiarostami uses documentaries and fiction films to examine the distinction between reality and fiction. Through the use of an arthouse style of filmmaking, the insertion of a surrogate director into the narrative, and a recurring breakdown in technology, Kiarostami demonstrates that film's ability to capture reality is a flawed, sometimes broken, endeavor.

Beatrice Ferrara looks at "Monument to dead television" which is the expression the British collective The Otolith Group uses to define its activity of recuperating long-lost quality films, and re-screening them in contemporary art museums and gallery spaces. What these films share is a cinematic vocation and a complex approach to the question of memory and migration in Europe, and to the role of images as testimonies or 
documents. This essay explores The Otolith Group's interest in such forgotten archives of modern television in order to unearth their significance for contemporary museums today.

Julio Bezerra views contemporary film as displaying a kind of "transnational new wave" that seems unique since the mid-60s. Filmmakers as diverse as Tsai Ming-Liang, Karim Aïnouz, and Apichatpong Weerasethakul, show a similar sensitivity towards the values of the world and of the cinema. What brings the work of these directors together is the taste for a realism more focused on the phenomenon of experience, on issues of skin and surface, and a different look at the body. His hypothesis is that the phenomenology of Merleau-Ponty provides us with valuable tools to broaden the debate. The discussion is carried out by an analysis of the work of Tsai MingLiang, Apichatpong Weerasethakul and Karim Aïnouz.

Andrew Ali Ibbi acknowledges that the emergence of indigenous film industries across the world has been seen by many as a threat to the influence of Hollywood on the movie scene. His article looks at the ideological influence of Hollywood on movies the world over. The Chinese, Indian and the Nigerian film industries are chosen as case studies because of their popularity in their continents and some parts of the world.

Luiza Lusvarghi claims that a new type of Brazilian drama series has taken place on local TV: the cop shows. Although they are not popular as the telenovela (soap operas), definitively they came to stay. International channels like Fox and HBO are benefited by Tax Benefits Rule which provides financial conditions for the production of those home market, and are now competing with the two greatest media Brazilian groups - Record and Globo.

Sara Marino reviews Dogville by Lars Von Trier through the perspective given by Hamid Naficy in his An Accented Cinema. She shows how identity is described and performed through the allegory of Grace and the image of the refugee, and the role homelessness and displacement play both for the filmmakers and the content of diasporic films.

Yasemin Kılınçarslan discusses Kunio Kato's film La Maison En Petits Cubes has has two dimensions. One of these is the content design, which depends on aristo aesthetic and the other one is the visual aesthetic, which depends on tranquil, simple, refreshing and relaxing traditional japan pictures like Ando Hirosige's. The director manages to configure a visual and content integrity between the form of human body and the design of the city. The human- city analogy is the key point to look at the human consciousnnes which inquiries the existansialim problems related to changing millieu.

Final article by Murat Akser hunts down and classifies the concept of the national as a discourse in Turkish cinema that has been constructed back in 1965, by the film critics, by filmmakers and finally by today's theoretical standards. So the questions he constantly askes throughout the essay are: Is what can be called part of national film culture and identity? Is defining a film part of national heritage a modernist act that is also related to theories of nationalism? Is what makes a film national a stylistic application of a particular genre (such as melodrama)? Does the allure of the film come from the construction of a hero-cult after a director deemed to be national?

2014 brings new edited books on cinema. Two such collections by Akser and Bayrakdar (2014) and Dina Iordanova and Stefanie ven de Peer, Film Festival Yearbook 6 are waiting their readers.

\section{REFERENCES:}

Akser, Murat and Deniz Bayrakdar eds. New Cinema, New Media: Reinventing Turkish Cinema. Newcastle upn Tyne: Cambridge Scholars Publishing, 2014.

Iordanova, Dina and Stefanie van de Peer. eds. Film Festival Yearbook 6: Film Festivals and The Middle East. St. Andrews: St. Andrews Film Studies, 2014. 